\title{
Microbial Mat Structures and role of microbes in Precambrian siliciclastic sedimentation: Evidence from Indian Proterozoic basins
}

\author{
${ }^{1}$ Department of Geological Sciences, Jadavpur University, Kolkata-700 032 \\ ${ }^{2}$ Department of Earth Sciences, Indian Institute of Technology Bombay, Powai, Mumbai-400076 \\ ${ }^{3}$ Department of Geology, University of Delhi, Delhi 110 007, India
}

(Received : 7/03/2019; Revised accepted : 6/04/2019)

https://doi.org/10.18814/epiiugs/2020/020010

Microbes had been the sole occupant of the early biosphere and they strongly controlled the evolution of lithosphere, hydrosphere, biosphere and atmosphere. Many Microbes could form mat like structure on sea floor. During the Precambrian these microbial mats had a strong influence on sedimentation, and they facilitated the formation of a variety of mat-induced sedimentary structures (MRS/MISS) in siliciclastic and carbonate rocks. In last two decades many of these structures have been identified from the Indian Proterozoic rocks. Observation from modern environments indicates the formation of mat related structures in preferred segments of the shallow marine domain. We also investigate the cause and effect relationship between the mat-growth and the sequence building pattern during the Precambrian. The commonly present HSTs compared to those of corresponding TSTs possibly indicates that microbial mat-infested sea floor impedes erosion, while concomitant sediment supply facilitated formation and preservation of regressive packages during the Precambrian.

\section{Introduction}

Microbes were the dominant life form on earth in absence of grazing organisms during the Precambrian time. Microbial mats influenced the sedimentation in many ways through trapping, binding baffling and biostabilization. Moreover, Microbes play a major role in biomineralization. Extracellular polymeric substances (EPS), embedded within the biofilms of micro-organisms, often form a thixotrophic layer enhancing cohesiveness of the sediments. It acts like a tough leathery material upon which micro-organisms leave their proxy records (Schieber et al., 2007). Precambrian carbonates received considerable attention than their siliciclastics counterpart for microbial mat. Enormous morphological and taxonomical variations in stromatolites possibly resulted from by the early cementation in carbonate rocks. On the other hand, lack of early cementation resulted in poor preservation of microbial structures in Precambrian siliciclastic rocks. However, last two decades witnessed extensive documentation of microbial mat-induced sedimentary structures from Precambrian siliciclastics, both in sandy and shaley intervals world over, a substantial component of which are recorded from India (Sarkar et al., 2004, 2006,2008, 2011, 2014, 2018; Samanta et al., 2015; Schieber et al., 2007; Noffke, 2008; Banerjee et al., 2010, 2014; Chakraborty et al., 2012 and many others). Davies et al. (2016) reported diverse kinds of microbial mat related sedimentary structures from different sedimentary environments in Phanerozoic. Microbial mat possibly diversified and expanded both siliciclastic shallow marine and continental settings soon after the Permo-Triassic biotic crisis (Chen et al., 2017). However, microbial mat signature is yet to be recorded in Phanerozoic siliciclastics of India. Potential microbial signatures, including pseudofossils and dubiofssils, discovered from Indian Proterozoic basins, created tremendous interests across the globe (Sarkar et al., 2005, 2006,2007, 2014; Banerjee and Jeevankumar, 2005; Schieber et al., 2007; Banerjee et al., 2010,2014; Samanta et al., 2015). Although limited studies contended for chronostratigraphic implications of MRS (Kumar and Ahmad, 2014), such claims remain largely unsubstantiated. The role of microbial mat on sedimentation dynamics remained the central theme in several studies (Sarkar et al., 2005, 2014; Banerjee and Jeevankumar, 2005; Chakraborty et al., 2012). The study of modern microbial mats provided additional clues for the interpretation of morphological variation in ancient intertidal-supratidal settings and resolving the origin of problematic features (Banerjee et al., 2010, 2014). The notion that the non-uniformitarian microbial mat influenced the Precambrian environment, taphonomy, depositional system and sequence building pattern is, nonetheless, yet to be consolidated. Generalization of the seldom perceived control of omnipresent mat ground on Precambrian sedimentation dynamics, bedforms migration, net sedimentation rate and sequence building is 
necessary to understand Precambrian depositional system in proper perspective.

Noffke et al. (2001) introduced the acronym MISS (microbially induced sedimentary structures) to include microbial mat originated features on clastic sediments. As many of these features could form by the action of physical forces on biostabilized sediment surfaces, an alternative acronym, MRS (mat-related structures), remained equally acceptable, particularly to consider the wide spectrum of microbial mat-related features (Schieber, 2004; Schieber et al., 2007; Eriksson et al., 2010; Sarkar et al., 2016). Authors will follow the latter acronym to describe all varieties of microbial mat structures in this discussion. Microbial mats formed in wide ranging depositional domains covering both marine and continental. While the microbial mat structures from siliciclastics was reported from $3.48 \mathrm{Ga}$ siliciclastics of the Dresser Formation, Pilbara in Australia (Noffke et al., 2013), the 1.8 Ga palaeodesert deposits of the Waterberg Group in South Africa recorded the oldest continental example (Eriksson et al., 2000). Increasing numbers of MRS have been described in recent years from some Precambrian basins of India (Fig.1) including Vindhyan basin (Sarkar et al., 2005, 2006, 2014; Banerjee and Jeevankumar, 2005; Banerjee et al., 2010, 2014), Chhattisgarh (Chakraborty et al., 2010; Sarkar et al. 2014), Cuddapah (Chakrabarti and Shome, 2010, Pranhita (Deb et al., 2007) and Marwar (Sarkar et al., 2008; Samanta et al., 2011, 2015; Kumar and Ahmad, 2016; Pandey and Sharma, 2018). Authors investigate microbial matoriginated structures within siliciclastic sedimentary succession from several Proterozoic basins of India and highlight the influence of microbial mat on sequence building pattern and sedimentation dynamics of Precambrian sedimentary succession. Authors have also discussed the significance of modern mat features for understanding the origin of mat-related structures.

\section{Microbial mat related (MRS) on modern environments}

Microbial mats grow abundantly on modern clastic sediments along the coastlines of the Gulf of Cambay (Fig.1d). Banerjee et al. (2014) recognized lateral variation in microbial mat features within a stretch of the coastal plain of the Gulf of Cambay. They noted increasing abundance of MRS accompanied by systematic variation in structures from the lower intertidal zone to the upper supratidal zone, resulting from decreasing wave/current actions, (Fig.2). The lower intertidal zone produced less diversified MRS including wrinkle structures, sieve-like surfaces and patchy ripples. While the reduced current action on the microbial mat layer as well as intermittent exposure led to the formation of diverse MRS including multidirectional ripples, patchy ripples, wrinkle structures, setulfs, sievelike surfaces, gas domes, reticulated surfaces, rolled-up mat fragments, and cracked mat surfaces within the upper intertidal zone (Fig. 3). Banerjee et al. (2014) also established the increased occurrences of petee ridges, gas domes and cracked mat surfaces from the lower to upper supratidal zones besides the presence of abundant cracked mat surfaces, petee ridges, gas domes and wrinkle structures in both zones (Fig.2; see also Gerdes et al., 2007; Bose and Chafetz, 2009; Banerjee, 2012, 2013). Further, Banerjee et al. (2014) extrapolated the distribution of MRS in modern environment for the high-resolution palaeo-environmental interpretation of the $\sim 1.6 \mathrm{Ga}$ Chorhat Sandstone

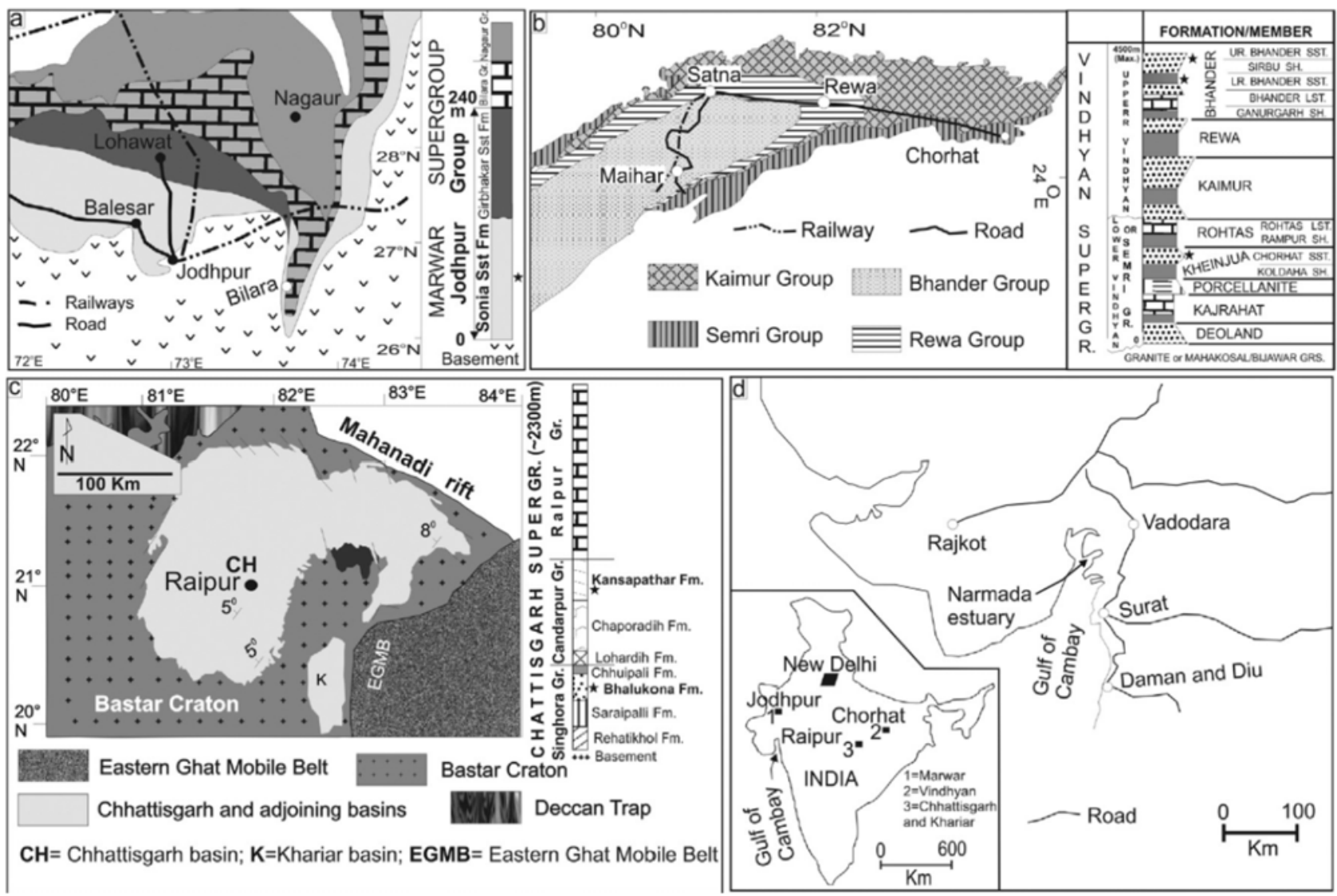

Figure 1. Studied Proterozoic basins, Marwar (a), Vindhyan (b), Chattishgarh (c) and the modern stretch along coastline, Gulf of Cambay (d).

Episodes Vol. 43, no. 1 
of the Vindhyan Supergroup. Sarkar et al. (2011) investigated setulf in detail, one of the least studied small-scale sedimentary structures within the microbial mat covered coastal plains of eastern India. They found these features formed by the adhesion of wind-deflated sands on microbial mat chips while the mat layer growing on the moist surfaces covered these minute structures within the littoral to supralittoral environments. They have identified same structures from the inferred similar coastal plain environment of the shallow marine facies

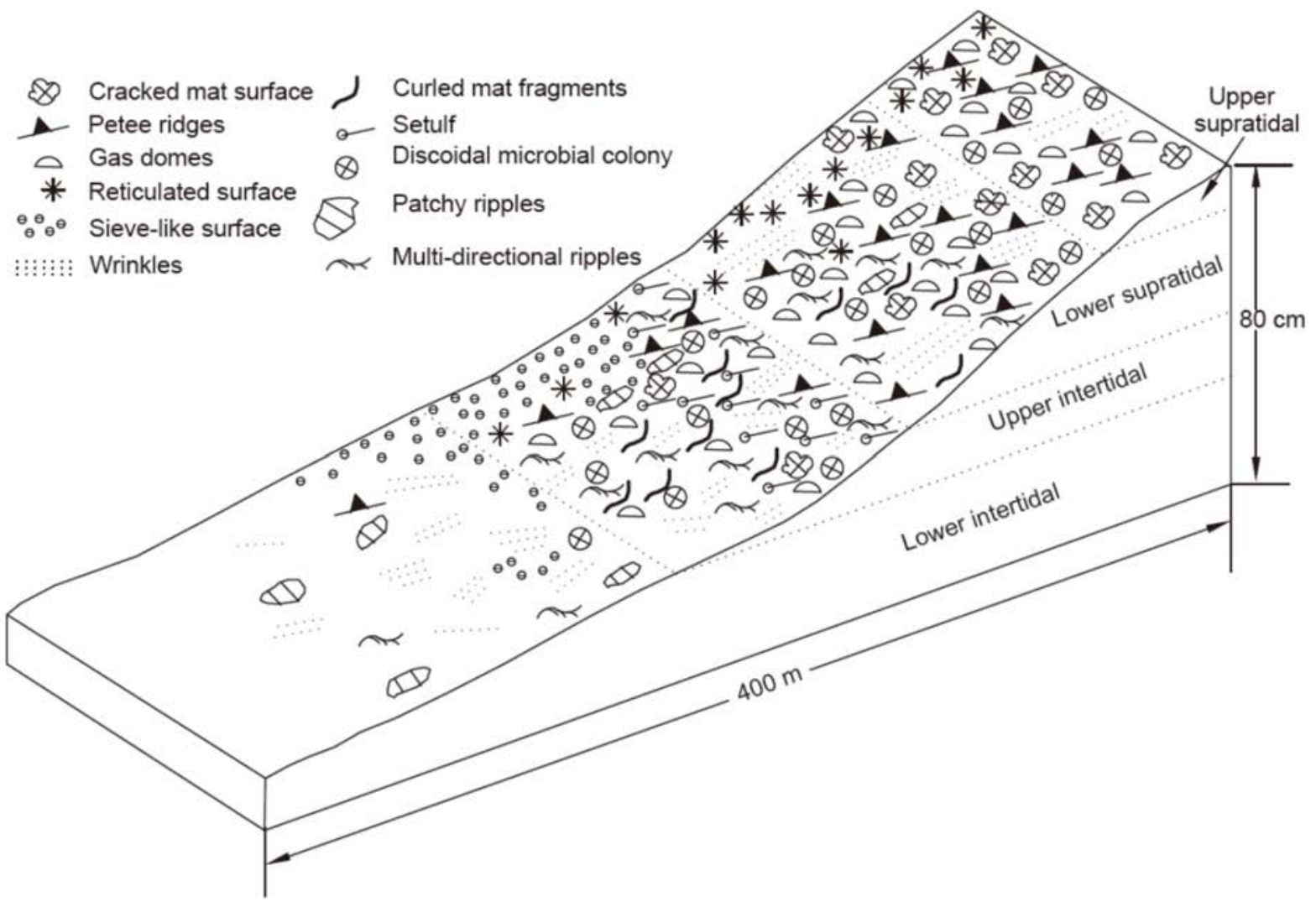

Figure 2. Distribution of microbial-mat related structures (MRS) within the coastal zones of Gulf of Cambay near Surat (note the variation in abundance of MRS within lower intertidal to supratidal zone)
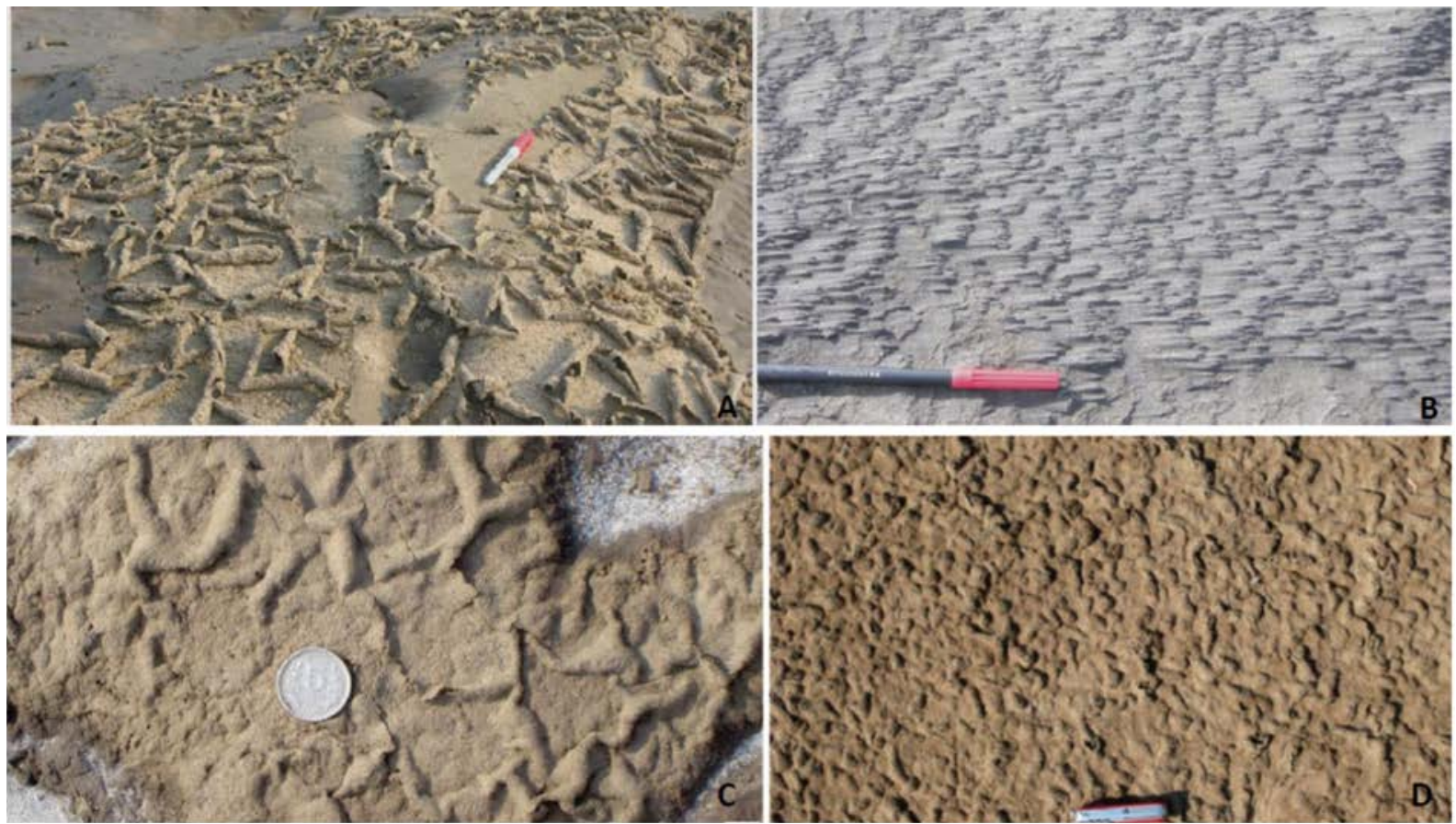

Figure 3. Modern MRS on coastal sediments of Gulf of Cambay, roll-up structure (A), setulf (B) petee ridges (C), domal structure (D) (pen length in $A=12.5 \mathrm{~cm}$, pen length in $B=14 \mathrm{~cm}$, coin diameter in $C=2.2 \mathrm{~cm}$, swiss knife in $D=9.1 \mathrm{~cm}$ ). 
of the Proterozoic Upper Bhander Sandstone, Vindhyan Supergroup (Fig.1b) and in Sonia Sandstone of Marwar Supergroup (Fig.1a). In both the ancient formations setulfs occur on bedding surfaces of wellsorted sandstones, and are associated with planar laminae, profound wave ripples, parting lineation, occasional rill marks and local swarms of current crescents.

The cm-scale, disc-shaped microbial colony (DMC) exhibiting a variety of internal structures is a unique feature of the coastal plains of the Gulf of Cambay. This feature exhibit rounded discs of a few mm reliefs, marked by sharp outline, with internal radial, concentric, reticulate or wrinkle features (Fig.4). Prominent grooves may divide the discs internally in places (see Banerjee et al., 2014). 'Discoidal microbial colony' is essentially a microbially-originated feature that
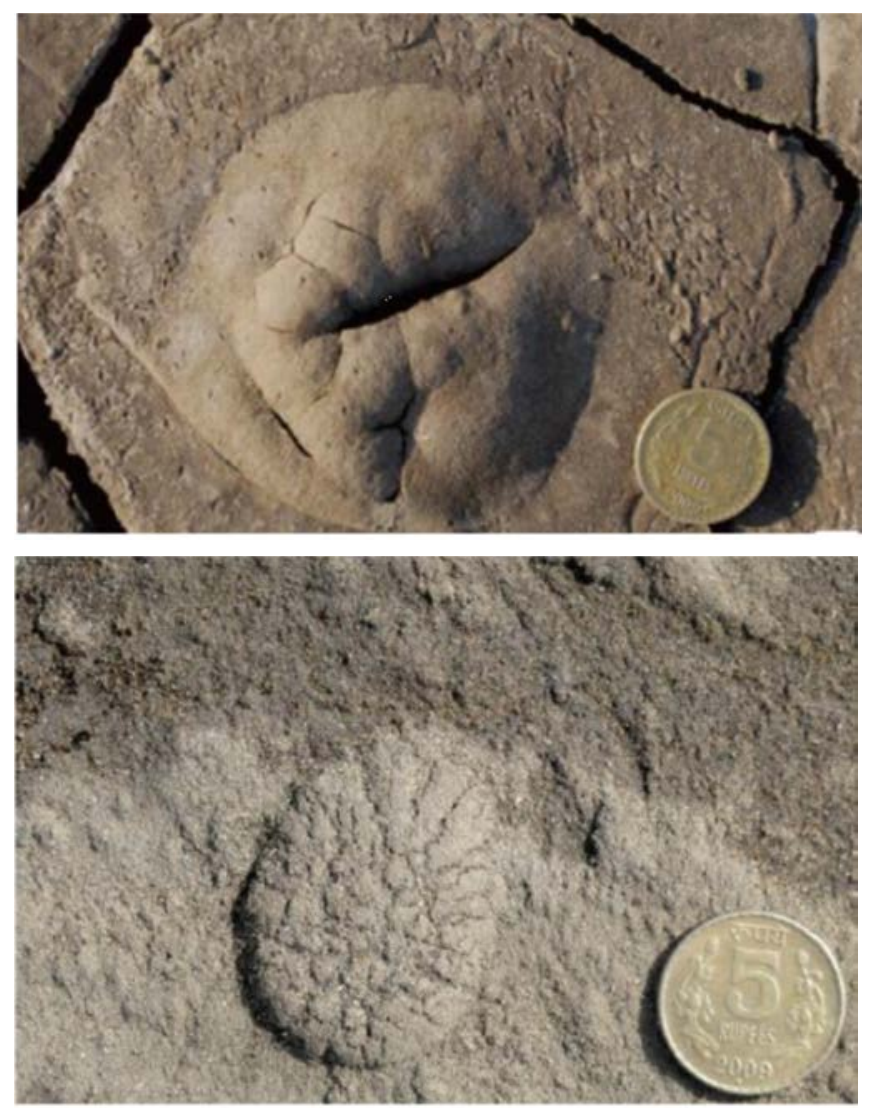

Figure 4. Discoidal microbial colony on modern coastal sediments: note a prominent groove with a few subordinate ones (top) and reticulate structures (bottom) (coin diameter $=2.2 \mathrm{~cm})$ resembles circular Ediacaran fossil, known as 'medusoid' in Precambrian rocks. Grazhdankin and Gerdes (2007) demonstrated unequivocal texture of microbial mats within the discoidal microbial colony in Neoproterozoics of Russia and ruled out its Ediacaran affinity.

Banerjee et al. (2010, 2014) and Sarkar et al. (2014, 2007) presented several examples of 'discoidal microbial colony' on siliciclastic rocks of the Vindhyan Supergroup and considered that both discoidal microbial colony and MRS lacks biostratigraphic significance and are not useful for the correlation of Precambrian stratigraphic successions. Similar features reported from the Bhander Formation in the Vindhyan Basin were considered earlier as Ediacaran fossils (see De, 2006). The recent chronostratigraphic information rules out the presence of any Ediacaran sedimentary rock within the Vindhyan Supergroup (cf. Rasmussen et al., 2002; Malone et al., 2008, Gilleaudeau et al., 2018).

\section{Mat features in ancient siliciclastics}

Schieber et al. (2007) presented a classification of MRS based largely on genetic processes involved, viz. mat growth, mat metabolism, physical mat destruction and mat decay and diagenesis. While the first two categories of structures are observed on the bedding surfaces, mat decay features are found on vertical sections across bedding. Sarkar et al. (2008) provided another classification of MRS that considers the role of mat, viz. mat layer, mat induced and mat protected types. Mat layer structures include those exhibiting in situ growth of microbial mat. The features include wide varieties of direct records of microbial mat originated discoidal bodies, often marked by small beads occurring within Chorhat Sandstone and Sirbu Shale of the Vindhyan Supergroup (Fig.5). These also include crumpled mat layers, mat curls, sand chips, kinneyia structures (Fig. 3, 6, Banerjee and Jeevankumar, 2005; Sarkar et al., 2004, 2006, 2014). Mat-induced feature reflects indirect indications of mat growth on substrate, including sand-cracks of different shapes including Manchuriophycus, petee ridges and domes (Fig.6, Sarkar et al., 2006, 2010; Banerjee et al., 2014). The mat protected features represent different varieties of patchy ripples, multidirectional ripples and palimpsest ripples.

\section{Microbial mat features in shale}

The documentation of the MRS remains challenging in finegrained rocks because of the inherent cohesiveness of mud. However,
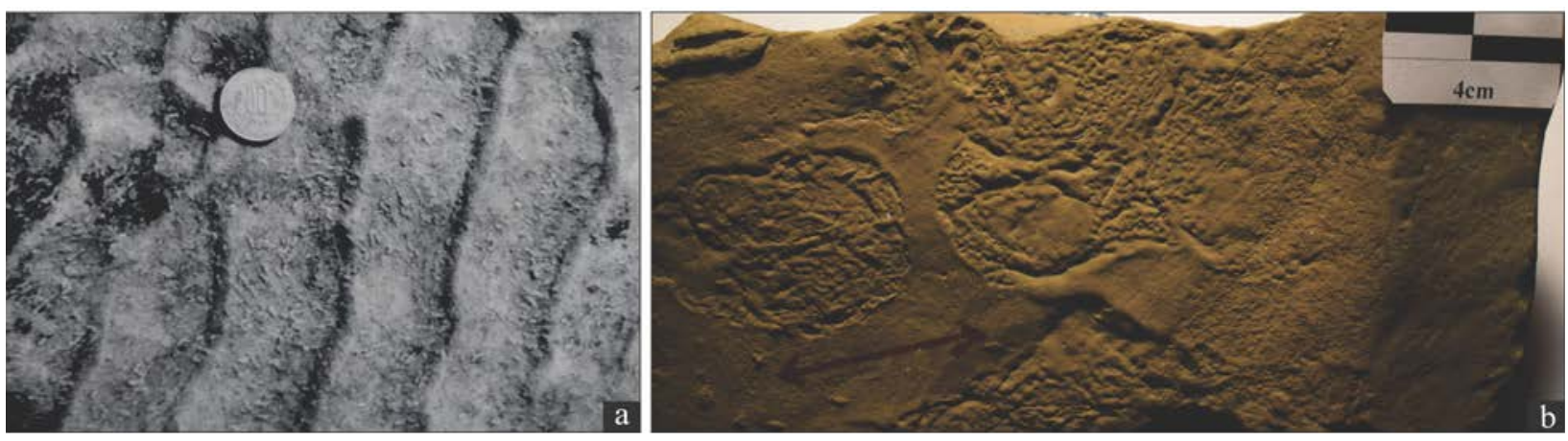

Figure 5. Microbial mat originated discoidal bodies, often marked by small beads occurring within Chorhat Sandstone (a) and mat impression at the undersurface of a bed in Sirbu Shale (b) (coin diameter in $a=2.1 \mathrm{~cm}$ ) 

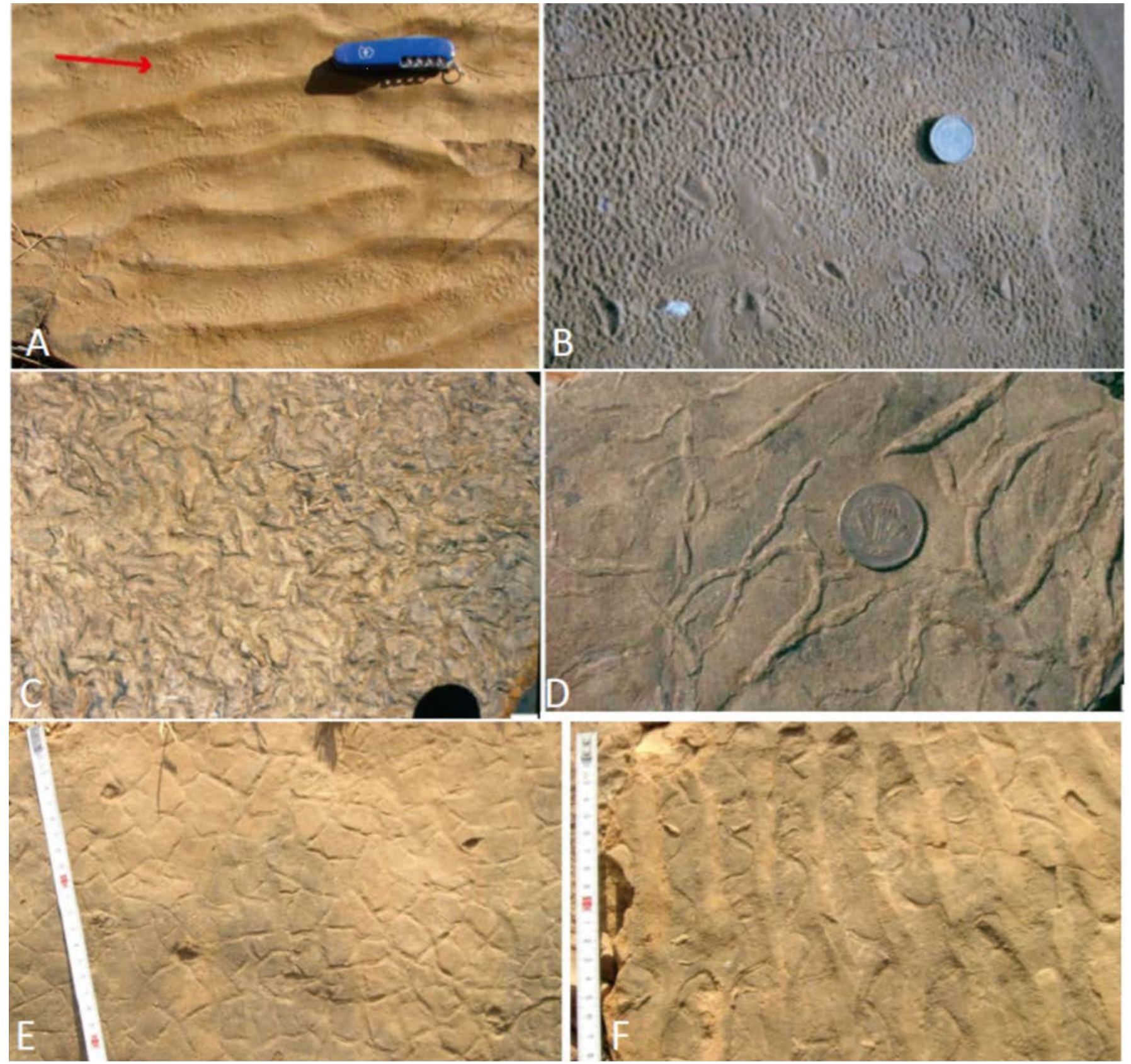

Figure 6. Microbial mat structures on bedding surfaces of the Chorhat Sandstone including wrinkle structures (A), kinneyia ripples (B), petee ridges ( $C$ and $D$ ), sand-cracks ( $E$ and $F$ ) (coin diameter in $B$ and $D=2.3 \mathrm{~cm}$, length of swiss knife in $A=9.1 \mathrm{~cm}$, len cap diametr in $C=3.6 \mathrm{~cm})$

petrographic investigation presents many features equivocal of microbial mat growth including wavy-crinkly laminae, extra-cohesive behavior of carbonaceous laminae exhibiting rolled and folded margins, 'teeth and socket' structure, pseudo cross-lamination, wavy pyritic laminae. Occurrence of these features within the organic-rich shales in Rampur and Bijaigarh Formations of the Vindhyan Supergroup indicates microbial mat colonization of the sediment depositional surfaces (Fig.7 Banerjee et al., 2006; Sur et al., 2006; Schieber et al., 2007; Deb et al., 2007). Although wavy and crinkly laminated microfabric suggests microbial mat growth on seafloor, the same lamina style may also be non-mat origin. A differential compaction of organic-rich layer against resistant particles like quartz silts, micro-nodules or fecal pellets may result the waviness in shale microfabric. Distal storm or turbidite beds may often overlie on growing mats causing interruption of microbial mat growth. Alternate deposition of mat layer and storm/turbidite beds may form 'striped shale' in the Somanpalli Formation (Schieber et al., 2007b). As microbial mat cover expands laterally on muddy substrate, clay drapes can result pseudo-cross-lamination at the edge of the expanding mat patches (Schieber et al., 2007b). This feature reflects the rapid reestablishment of mats on top of the recently deposited clay drapes, followed by their lateral expansion (Schieber, 1986). The mat layer may often display abundant micas (flypaper effect, Fig.8a), that essentially reflects the trapping actions of microbial filaments (Schieber et al., 2007). The microbial originated black shales often reveal roll-up structures, over folded mat layers as well as torn pieces of irregular mat fragments displaying frayed edges (Banerjee et al., 2006; Sur et al., 2006; Schieber et al., 2007; Fig. 8b). These features 


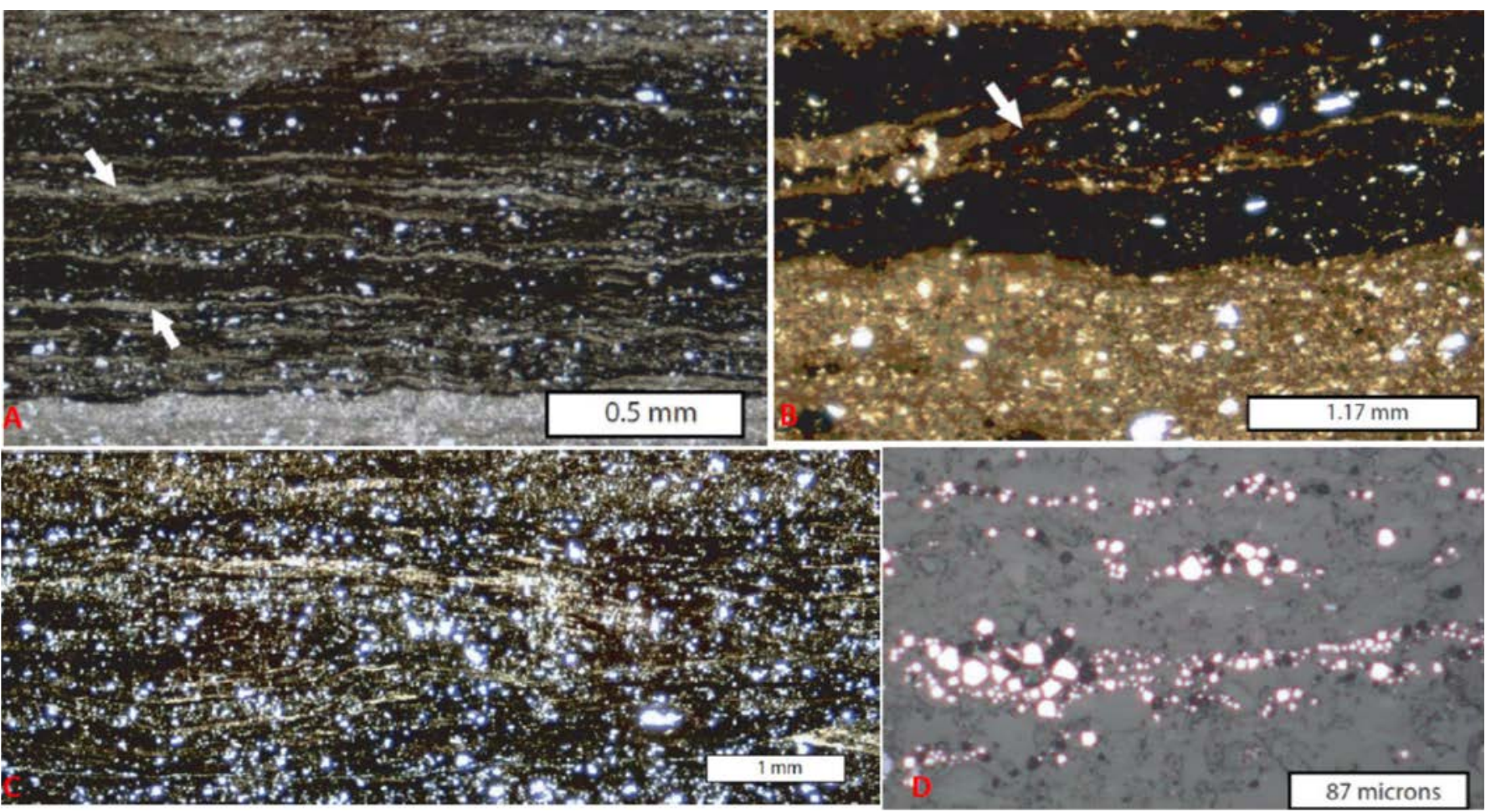

Figure 7. Microbial mat features in Precambrian black coloured Rampur shales including wavy crinkly laminae (A) folded carbonaceous laminae (B), contorted mat layer (C) and wavy pyritic laminae (D).

result by the physical destruction and subsequent transportation of extra-cohesive microbial mat bound mud layer. The wavy, pyritic laminae probably represent the mineralized microbial mat laminae (Fig.7, Schieber 1989). The decay of organic matter beneath a growing mat may form local anaerobic condition that may induce formation of pyrite in marine environment. The availability of iron determines whether the tiny pyrite grains remain sprinkled within the carbonaceous laminae or strongly pyritic laminae forms that mimic the wavy-crinkly anastomosing mat texture (Sur et al., 2006). Pyrite tends to be more disseminated in case of Phanerozoic black shale (Schieber, 2007).

Microbial mat-originated Precambrian black shale may contain high amount of organic content, TOC value (total organic carbon) exceeding 2 to $5 \mathrm{wt} \%$, although thermally over mature (Banerjee et al., 2006). Banerjee et al. (2006), related the organic-rich shale in the Vindhyan Supergroup to maximum flooding surfaces, as low rate of sedimentation facilitated the prolific mat growth enhancing organic matter content in sediments. Microbial mats remained primary product in case of Precambrian black shale while organic content of the Phanerozoic black shales is related to planktonic productivity (Banerjee et al., 2006; Schieber et al., 2007). Compared to the deep basinal origin of the Phanerozoic black shale, the microbial matoriginated Phanerozoic variety typically formed in shallow subtidal depositional conditions (see Sur et al., 2006; Banerjee et al., 2006; Schieber, 2007); mats stabilized sediments, recycled organic matters, and remained the primary producers during the Precambrian (Schieber et al., 2007).

Chemical analysis, including carbon and sulfur isotopic and biomarker studies of the microbial mat layer provide information regarding the types of microbes. Deb et al. (2007) presented biomarker data from black shale and stromatolitic carbonates of the Raipur Group of the Chattisgarh Supergroup and indicated bacterial origin of the hopane-dominated biomarker assemblage. Sarkar et al. (2010) considered stratified water column for the Vindhyan Sea with anoxic sulfidic conditions on the basis of heavy a $^{34} \mathrm{~S}$ values (25.5 $\pm 8.7 \%$ \%) in sedimentary pyrites associated with black shale in the Bijaigarh Shale Member. While Singh et al. (2018) considered euxinic condition for the black shale of Arangi, Rampur and Bijaigarh Formations on the basis of trace element concentration.

\section{Occurrence of MRS in different basins}

The following sections present a brief description of the MRS features reported from Proterozoic sedimentary basins of India in their depositional context.

\section{Vindhyan Basin}

Although the Vindhyan Supergroup received considerable attention for putative trace fossils (Sarkar et al., 1996; Seilacher et al., 1998), oldest red algae (Begtson et al., 2017) and well preserved stromatolites in carbonate rocks (Sarkar et al., 1996; Chakraborty et al., 2005; Banerjee et al., 2007; Sharma et al., 1996), it is also well known globally for superb preservation of delicate MRS (Sarkar et al., 2004, 2005, 2006;2016a,b; Banerjee and Jeevankumar, 2005; Banerjee et al., 2006, 2010, 2014; Sarkar and Banerjee, 2007; Schieber et al., 2007b; Eriksson et al., 2010). The two-tiered Vindhyan Supergroup consists of alternate HSTs and TSTs, separated by condensed zones (Bose et al., 2001). The deposition of sediments took place in wide ranging environments including outer to inner shelf, littoral, fluvial with local eolian patches (Bose et al., 2001). Organic-rich shales (TOC content exceeding 1.5\%) characterize the condensed zones (Banerjee et al., 2006; Sur et al., 2006). Wavy crinkly 

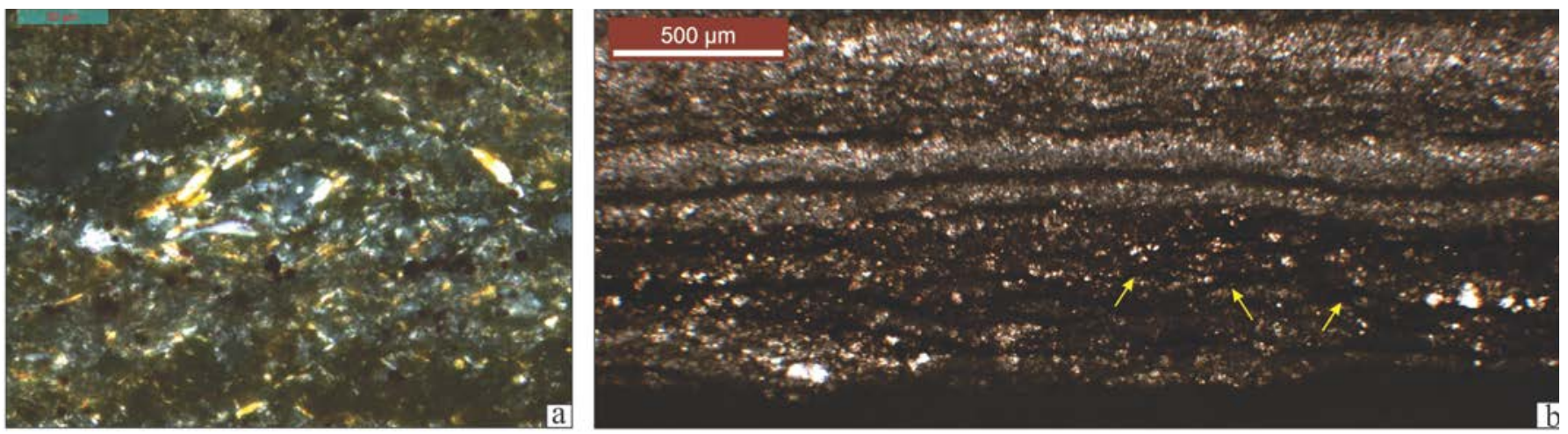

Figure 8. Microbial mat layer show flypaper effect (a) and displaying frayed edges(b)

carbonaceous laminae, pyritic laminae, pseudo cross-strata and rolledup and folded carbonaceous laminae in Rampur Shale, Sirbu Shale and in Kajrahat Formation suggest microbial mat growth in mid- to outer-shelf depositional conditions (Banerjee et al., 2006). Banerjee and Jeevankumar (2005) recorded systematic changes in wrinkle structures within the middle to inner shelf originated Koldaha Shale in response to variation in energy conditions of the depositional environment. While the low-relief wrinkles form in deeper setting, the high relief and more complex varieties form by the strong shear on microbial mat covered sandy surfaces (Banerjee and Jeevankumar, 2005). The shelf-originated Sirbu Shale exhibits broadly similar features, but include wide variations of patchy mat fragments and disc-shaped impressions at the soles of the storm-originated sandstone beds (Sarkar et al., 2016). However, the best preservation of MRS occurs on shallow subtidal to supratidal segments of the HSTs, which are superbly exposed in the Chorhat Sandstone and the Upper Bhander Sandstone (Sarkar et al., 2006; 2014a). The features include sandcracks of different shapes and sizes, gas domes, petee ridges, wrinkle structures, kinneyia, palimpsest ripple, patchy ripples, rolled-up mat fragments and microbial sand chips. Microbial mat features are well preserved at the interfaces of vertically stacked storm sandstone beds, with no visible signs of erosion (Banerjee, 1997; Sarkar et al., 2006; Bose et al., 2007). Microbial mats must have protected sandstone beds from erosive actions of storms (Sarkar et al., 2006). Sarkar et al. (2016a) compared similar sets of MRS on bedding surfaces between siliciclastics and carbonates in the Chorhat Sandstone and the Bhander Limestone respectively. They attributed the preservation of the MRS within limestone possibly because of delayed cementation.

\section{Marwar Basin}

Abundant microbial mat related structures within the shore face to supra-littoral-originated Neoproterozoic Sonia Sandstone indicates unusually high cohesiveness of sandy sediments. A large variety of microbial MRS at different stratigraphic level within the lower HST comprising the Sonia Sandstone indicates intermittent sedimentation and severely curtailed sediment reworking (Sarkar et al., 2008; Samanta et al., 2011). The littoral-supra-littoral environments characterize wide varieties of wrinkles, patchy ripples and mat colonies whereas high littoral to supra-littoral zones exhibit crumpled structures. The supra-littoral zone shows abundant desiccation cracks and petee ridges. Ripples may occur as casts on the under surfaces of the overlying storm beds in vertically amalgamated sandstone beds. The near-planar, non-erosive beds resemble distal storm deposits.
Samanta et al. (2011) presented many varieties of features on the vertical section across microbial mat layers to reflect decay and diagenesis beneath mat layers. Kumar and Ahmad (2014) reported several examples of microbial growth related structures, including morphologies like Arumberia banksi, Rameshia rampurensis and Jodhpuria circularis, which they argued to represent Neoproterozoic varieties, as originally considered by Glaessner and Walter (1975). However, Davies et al. (2016) demonstrated many examples of Arumberia within Phanerozoic deposits and ruled out biostratigraphic relevance of these features, and even debated for their abiotic origin.

\section{Chhattisgarh Basin}

A wide spectrum of MRS occurs within two stratigraphic intervals, the Bhalukona Formation of Singhora Group and the Kansapathar Formation of Chandarpur Group within the Chhattisgarh Supergroup and Khariar Group (Chakraborty et al., 2012; Sarkar et al., 2014). The medium to fine-grained sandy lower to upper shoreface barinterbar package of the Bhalukona Formation represents a lowstand systems tract deposits consisting of m-thick 'parasequence's. The forced regressive middle to upper shore face deposits of the Kansapathar Formation represents deposition under fair-weather and storm-wave influence. The well-sorted sandstones with retrogradational stacking in the Lower Sandstone Formation of the Khariar Group represent a transgressive shoreface beach deposits formed in shallow marine environment. Palimpsest ripples, torn mat fragments, wrinkle structures, setulfs, cracks and petee ridges occur on the sandstone bedding surfaces, whereas vertical sections exhibit highly irregular, wavy and crenulated sand laminae within the Bhalukona Sandstones. A preferential concentration of MRS occurs in the lower to middle/upper shoreface sandstones constituting the progradational packages within the Kansapathar Sandstone. Wrinkle structures in lower shore face cover both crests and troughs of ripples, while those in upper shore face occur exclusively within the troughs of ripples (Chakraborty et al., 2012).

\section{Other Precambrian basins}

MRS including wrinkle structures, kinneyia ripples, palimpsest ripples, elephant skin structures occur within the basal Gulcheru Formation ( 1.8 Ga) of the Proterozoic Cuddapah Supergroup within the intertidal environment (Chakrabarti and Shome, 2012). Deb et al. (2007) reported striped shale and wavy laminae within black mudstones and shales of the Mesoproterozoic Somanpalli Group in 
the Pranhita-Godavari Basin. Van Loon and Mazumder (2013) mentioned about wavy to undulatory bedding surfaces within the shales comprising the Palaeoproterozoic Chaibasa Formation in Singhbhum craton, which they inferred as equivalents of stromatolites. Mukhopadhyay and Thorie (2016) reported MRS within the mixed siliciclastic carbonate succession of the Proterozoic Kunihar Formation, Simla Group, including wrinkle structures, kinneyia ripples, domal structures, sand chips, palimpsest and patchy ripples (Mukhopadhyay and Thorie, 2016).

\section{Discussion and conclusions}

Study of modern microbial mat reveals maximum diversification of MRS in littoral to supra-littoral environments. The MRS in modern environment provides useful insights for the palaeo-environmental implications of similar features in ancient siliciclastics. However, modern MRS is essentially investigated in peritidal settings while MRS formed in wide ranging depositional conditions in the past. Microbial mat growth has been documented in varied depositional conditions from shallow intertidal-supratidal to offshore in several Precambrian basins in India. While petee ridges, wrinkle marks, gas domes sand-cracks, multi-directed ripple marks, setulf, and sievelike surfaces, occur at the shallowest part of the marine basins, rollup structures, wrinkle structures, kinneyia and patchy ripples occur within a broad range of palaeogeographic settings from the supratidal to subtidal conditions. Whereas, features like setulf and petee ridges are definite indicators of littoral environment. Preservation of delicate textural details like wavy-crinkly, carbonaceous laminae, wavy pyritic laminae and torn pieces of mat fragments indicates microbial mat growth in both shallow and deep subtidal environments. Various morphologies of 'discoidal microbial colonies' provide alternate and more plausible explanations of microbial origin of similar features in Precambrian rocks.

Unique characteristics of microbial mat structures provide valuable insights to examine microbial life in other terrestrial planet like Mars. Noffke (2015) recently compared MRS formed in earth with those occur in Mars on the basis of images obtained by Curiosity Rover mission. Sandstone beds of the $<3.7$ Ga Gillespie Lake Member on Mars displays cm- to m-scale structures similar to terrestrial MRS including erosional remnants and pockets, mat chips, roll-ups, desiccation cracks and gas domes (Noffke, 2015). MRS has been investigated in relation to sequence building pattern in a few studies. Exceptional preservation of MRS in Vindhyan, Marwar, Chhatisgrah and Khariar basins allows to investigate the role of microbial mat on sequence building pattern during the Precambrian (Sarkar et al., 2005, 2016a: Banerjee and Jeevankumar, 2005; Chakraborty et al., 2012). These authors also present sequence stratigraphic context of MRS in four Precambrian successions, namely the Marwar Supergroup, Vindhyan Supergroup, Chhattisgarh Supergroup and the Khariar Group. These siliciclastic successions exhibit contrasting trends of sequence building in comparison to those in Phanerozoic sedimentary basins. These Precambrian sequences generally lack of well-developed transgressive systems tracts (TSTs), instead consists dominantly of stacked prograding and aggrading 'normal regressive' systems tracts. While the Phanerozoic sequences exhibit fully developed TSTs in between regressive systems tracts (LSTs and HSTs; Vail et al., 1977; van Wagoner et al., 1988, 1990) and thus the formation and the preservation of transgressive systems tracts may represent a key difference between the Precambrian and the Phanerozoic sequence architecture. Sarkar et al. (2005, 2016) addressed the issue of absence of transgressive shales or thinning of transgressive deposits in Precambrian sequences. A combination of low gradients of sea floor that promote rapid transgressions and a low rate of sedimentation explains the absence of transgressive deposits in the studied Precambrian sequences. In several cases, the record of transgression is marked by a few cm-thick transgressive lags, forming stacked highstand systems tract deposits (Sarkar et al., 2005,2016; Banerjee et al., 2005; see also Catuneanu and Eriksson, 2007). Prolific growth of microbial mats below the fair weather wave-base prevented erosion of microbially bound sediments (Sarkar et al., 2005). Stacked packages of normal regressive systems tract, therefore, should characterize the sequence stratigraphic architecture of the Precambrian successions instead of transgressive-regressive systems tract as usually observed in the Phanerozoic successions. Mat-infested sea-floor might have restricted erosion and concomitant sediment supply and facilitated formation and preservation of forced regressive sedimentary unit in the sequence architecture of the Precambrian formations (Chakraborty et al., 2012; Sarkar et al., 2005). Future research is likely to consolidate ideas proposed in this paper.

\section{Acknowledgements}

The authors acknowledge their respective institutions for providing infrastructural facilities.

\section{References}

Banerjee, S. (2013). Microbial mat-related peculiar tunnels and cracks from modern supratidal environment, Gulf of Cambay, India. International Journal of Earth Sciences 102, 2223.

Banerjee, S. and Jeevankumar, S., (2005). Microbially originated wrinkle structures on sandstone and their stratigraphic context: Palaeoproterozoic Koldaha Shale, central India. Sedimentary Geology, 176, 211-224.

Banerjee, S., (1997). Facets of the Mesoproterozoic Semri Sedimentation in Son valley, India. Unpublished Ph.D. thesis, Jadavpur University, Kolkata-32.

Banerjee, S., (2012). Discoidal microbial colonies. International Journal of earth Sciences, 101, 1343.

Banerjee, S., Bhattacharya, S.K. and Sarkar, S., (2007). Carbon and oxygen isotopic variations in peritidal stromatolite cycles, Paleoproterozoic Kajrahat Limestone, Vindhyan basin of central India. Journal of Asian Earth Sciences, 29, 823-831.

Banerjee, S., Dutta, S., Paikaray, S. and Mann, U., (2006). Stratigraphy, sedimentology and bulk organic geochemistry of black shales from the Proterozoic Vindhyan Supergroup (central India). Journal of Earth Systems Science, 115, 37-48.

Banerjee, S., Sarkar, S., Eriksson, P.G. and Samanta, P., (2010). Microbially related structures in siliciclastic sediment resembling Ediacaran fossils: examples from India, ancient and modern. In: Microbial Mats: Modern and Ancient Microorganisms in Stratified Systems (Eds. J. Seckbach and A. Oren), Springer-Verlag, Berlin, 111-129.

Banerjee, S., Sarkar, S., Eriksson, P.G., (2014). Palaeoenvironmental and biostratigraphic implications of microbial mat-related structures: examples from modern Gulf of Cambay and Precambrian Vindhyan basin. Journal of Paleogeography, 3, 127144.

Bengtson, S., Sallstedt T., Belivanova, V., Whitehouse, M., (2017). Three-dimensional preservation of cellular and subcellular 
structures suggests 1.6 billion-year-old crown-group red algae, PLOS Biology,15(3).

Bose, P.K., Sarkar, S., Banerjee, S. and Chakraborty, S., (2007). Matrelated features from the Vindhyan Supergroup in central India. In: Schieber, J., Bose, P.K., Eriksson, P.G. Banerjee, S., Sarkar, S., Catuneanu, O., and Altermann, W. (Eds.), An Atlas of Microbial Mat Features Preserved within the Clastic Rock Record, Elsevier, 181-188.

Bose, S., Chafetz, H.S., (2009). Topographic control on distribution of modern microbially induced sedimentary structures (MISS): A case study from Texas coast. Sedimentary Geology, 213, 136149.

Bose, P.K., Sarkar, S. Chakraborty, S. Banerjee, S. (2001). Overview of the Meso- to Neoproterozoic evolution of the Vindhyan basin, Central India. Sedimentary Geology, 141/142, 395-419.

Catuneanu, O., Eriksson, P.G., (2007). Sequence stratigraphy of the Precambrian. Gondwana Research,12, Issue-4, 560-565.

Chakrabarti, G., Shome, D., (2010). Interaction of microbial communities with clastic sedimentation during Palaeoproterozoic time - An example from basal Gulcheru Formation, Cuddapah basin, India. Sedimentary Geology, 226, 22-28.

Chakraborty, P.P. and Sarkar, S., (2005). Episodic emergence of offshore shale and its implication: Late Proterozoic Rewa Shale, Son Valley, central India. Journal Geological Society of India, 66, 699-712

Chakraborty, P.P., Das, P., Saha, S., Das, K., Mishra, S.R., Paul, P., (2012). Microbial mat related structures (MRS) from Mesoproterozoic Chhattisgarh and Khariar basins, Central India and their bearing on shallow marine sedimentation. Episodes 35, 1-11.

Chakraborty, P.P., Dey, S., Mohanty, S.P., (2010). Proterozoic platform sequences of peninsular India: Implications towards basin evolution and Supercontinent assembly. Journal of Asian Earth Sciences, 39, 589-607.

Chen, Z.Q., Zhou, C., Stanley, J.G., (2017). Biosedimentary records of China from the Precambrian to present. Palaeogeography Palaeoclimatology Palaeoexology, 474, 1-6

Davies, N.S., Liu, A.G., Gibling, M.R., Miller, R.F., (2016). Resolving MISS conceptions and misconceptions: A geological approach to sedimentary surface textures generated by microbial and abiotic processes. Earth-Science Reviews, 154, 210-246

De, C., (2006), Ediacara fossil assemblage in the Upper Vindhyans of central India and its significance. Journal of Asian Earth Science, 27, 660-683.

Eriksson, P.G., Sarkar, S., Banerjee, S., Porada, H., Catuneanu, O., Samanta, P., (2010). Paleoenvironmental context of microbial matrelated structures in siliciclastic rocks: Examples from the Proterozoic of India and South Africa. In: Microbial Mats: Modern and ancient Microorganisms in Stratified Systems (Eds. J. Seckbach and A. Oren), Springer-Verlag, Berlin, 14, 73108.Eriksson, P.G., Simpson, E., Eriksson, K., Bumby, J.Adam., \& Steyn, George. L., Sarkar, S., (2000). Muddy Roll-up Structures in Siliciclastic Interdune Beds of the c. $1.8 \mathrm{Ga}$ Waterberg Group, South Africa. Palaios, 15, 177-183.

Gerdes, G., (2007). Structures left by modern microbial mats in their host sediments. In: Schieber, microbial mat features in mudstones of the Mesoproterozoic Somanpalli Group, Pranhita-Godavari basin, India. In: Schieber, J., Bose, P.K., Eriksson, P.G. Banerjee, S., Sarkar, S., Catuneanu, O., and Altermann, W. (Eds.), An Atlas of Microbial Mat Features Preserved within the Clastic Rock Record, Elsevier, 5-38.

Gilleaudeau, G.J., Sahoo, S.K., Kah, L.C., Henderson, M.A., Kaufman, A.J., (2018). Proterozoic carbonates of the Vindhyan Basin, India: Chemostratigraphy and diagenesis. Gondwana Research, 57, 10-25.
Glaessner, M.F., Walter, M.F., (1975). New Precambrian fossils from the Arumbera Sandstone, Northern Tertiary, Australia. Alcheringa, 1, 59-69.

Grazhdankin, D., Gerdes, G., (2007). Ediacaran microbial colonies. Lethaia, An International Journal of Palaeontology and Stratigraphy, 40, 201-210

Kumar, S., Ahmad, S., (2014). Microbially induced sedimentary structures (MISS) from the Ediacaran Jodhpur Sandstone, Marwar Supergroup, western Rajasthan. Journal of Asian Earth Sciences, 91, 352-361.

Malone, S.J., Meert, J.G., Banerjee, D.M., Pandit, M.K., Tamrat, E., Kamenov, G.D., Pradhan, V.R., Sohl, L.E., (2008). Paleomagnetism and detrital zircon geochronology of the Upper Vindhyan sequence, Son Valley and Rajasthan, India: a ca. 1000 Ma closure age for the Purana basins? Precambrian Research, 164, 137-159.

Mukhopadhyay, A., Thorie, A., (2016). Comparative study of two relatives, MISS and Stromatolites: example from the Proterozoic Kunihar Formation, Simla Group, Lesser Himalaya. Arabian Journal of Geoscience 9, DOI: 10.1007/s12517-0162549-9.

Noffke, N., Gerdes, G., Klenke, T., Krumbein, W. E., ( 2001). Microbially induced sedimentary structures - a new category within the classification of primary sedimentary structures. Journal of Sedimentary Research 71 649-656.

Noffke, N., (2008). Turbulent lifestyle: Benthic cyanobacteria on Earth's sandy beaches today and 3 billion years ago. GSA Today, 18, 4-9.

Noffke, N., (2015). Ancient Sedimentary Structures in the $<3.7 \mathrm{Ga}$ Gillespie Lake Member, Mars, That Resemble Macroscopic Morphology, Spatial Associations, and Temporal Succession in Terrestrial Microbialites. Astrobiology, 15, 169-192.

Noffke, N., Awramik, S.M., (2013). Stromatolites and MISSDifferences between relatives. GSA Today, 23, 4-9.

Patranabis-Deb, S.P., Schieber, J., Chadhuri, A.K., (2007). In: Schieber, microbial mat features in mudstones of the Mesoproterozoic Somanpalli Group, Pranhita-Godavari basin, India, In: Atlas of microbial mat features preserved within the siliciclastic rock record, 171-180.

Rasmussen, B., Bose, P.K., Sarkar, S., Banerjee, S., Fletcher, I.R., McNaughton, N.J., (2002). 1.6 Ga U-Pb zircon age for the Chorhat Sandstone, lower Vindhyan, India: possible implications for early evolution of animals. Geology, 30, 103-106.

Sarkar, S., Chakraborty, P.P., Bose, P.K., (1996).Proterozoic Lakheri Limestone, Central India: Facies, Paleogeography and Physiography, in Bhattacharya, A., ed., Recent Advances in Vindhyan Geology: Geological Society of India Memoir, 36, 525.

Sarkar, S., Banerjee, S., Eriksson, P.G., Catuneanu, O., (2005). Microbial mat control on siliciclastic Precambrian sequence stratigraphic architecture: examples from India- Sedimentary Geology, 176, 195-209.

Sarkar, S., Banerjee, S., (2007). Some unusual and/or problematic inferred mat-related. Atlas of microbial mat features preserved within the clastic rock record, 145-147.

Samanta, P., \& Mukhopadhyay, S., Sarkar, S., \& Eriksson, P.G., (2015). Neoproterozoic substrate condition vis-à-vis microbial mat structure and its implications: Sonia Sandstone, Rajasthan, India. Journal of Asian Earth Sciences, 106, 186-196.

Samanta, P., Mukhopadhyay, S., Mandal, A., Sarkar, S., (2011). Microbial mat structures in proûle: the Neoproterozoic Sonia Sandstone, Rajasthan, India. Journal of Asian Earth Sciences, 40, 542-549.

Sarkar, A., Chakraborty, P.P., Mishra, B., Bera, M.K., Sanyal, P., and 
Paul, S., (2010). Mesoproterozoic sulphidic ocean, delayed oxygenation and evolution of early life: sulphur isotope clues from Indian Proterozoic basins. Geological Magazine, 147, 206294.

Sarkar, S., Banerjee, S and Eriksson, P.G., (2004). Microbial mat features in sandstone illustrated. In: Eriksson, P.G., Altermann, W., Nelson, W., Mueller, D.R. and Catuneanu, O. (Eds.), The Precambrian Earth: Tempos and Events. Elsevier, Amsterdam, 673-675.

Sarkar, S., Banerjee, S., Samanta, P, Chakraborty, P.P., Mukhopadhyay, S. and Singh, A.K., (2014). Spectral variation of Microbial mat records in siliciclastic rocks: examples from Four Indian Proterozoic basins and their modern equivalents in Gulf of Cambay. Journal of Asian Earth Sciences, 91, 362-377.

Sarkar, S., Banerjee, S., Samanta, P. and Jeevankumar, S., (2006). Microbial mat-induced sedimentary structures and their implications: examples from Chorhat Sandstone, M.P., India. Journal of Earth Systems Science, 115, 49-60.

Sarkar, S., Choudhuri, A., Mandal, S., Eriksson, P.G., (2016). Microbial mat-related structures shared by both siliciclastic and carbonate formations. Journal of Palaeogeography, 5, 278-291.

Sarkar, S. Samanta, P., Altermann, W., (2011). Setulfs, modern and ancient: Formative mechanism, preservation bias and palaeoenvironmental implications. Sedimentary Geology, 238, 7178.

Sarkar, S., Bose, P.K., Samanta, P., Sengupta, P., Eriksson, P.G., (2008). Microbial mat mediated structures in the Ediacaran Sonia Sandstone, Rajasthan, India, and their implications for Proterozoic sedimentation. Precambrian Research, 162, 248-263.

Schieber, J., (1986), The possible role of benthic microbial mats during the formation of carbonaceous shales in shallow Proterozoic basins: Sedimentology, 33, 521-536.

Schieber, J., (1989), Pyrite mineralization in microbial mats from the Mid-Proterozoic Newland Formation, Belt Supergroup, Montana, U.S.A.: Sedimentary Geology, 64, 79-90.

Schieber, J., (2004), Microbial Mats in the Siliciclastic Rock Record: A Summary of Diagnostic Features. In: P.G. Eriksson, W. Altermann, D. Nelson, W.U. Mueller, O. Catuneanu, and K. Strand (editors), The Precambrian Earth: Tempos and Events, Developments in Precambrian Geology, Elsevier, 663-672.

Schieber, J., Bose, P.K., Eriksson, P.G. Banerjee, S., Sarkar, S., Catuneanu, O. and Altermann, W., (2007). An Atlas of microbial mat features preserved within the siliciclastic rock record. Elsevier Science, Amsterdam, 311

Schieber, J., Sur, S. and Banerjee, S., (2007). Benthic microbial mats in black shale units from the Vindhyan Supergroup, Middle
Proterozoic of India: the challenges of recording the genuine article. An Atlas of microbial mat features preserved within the clastic rock record, 189-197

Schieber, J., Bose, P.K., Eriksson, P.G. Banerjee, S., Sarkar, S., Catuneanu, O. and Altermann, W.,(2007) (Eds.) Benthic microbial mats as an oil shale component: Green River Formation (Eocene) of Wyoming and Utah. An Atlas of Microbial Mat Features Preserved within the Clastic Rock Record, Elsevier, 225-232.

Seilacher, A., Bose, P.K., Pfluger, F., (1998). Triploblastic Animals More Than 1 Billion Years Ago: Trace Fossil Evidence from India. Science, 282, 80-83.

Sharma, M., Pandey, S.K., Ahmad, S., Kumar, K., Ansari, A.H., (2018). Observations on the ichnospecies Monomorphichnus multilineatus from the Nagaur Sandstone (Cambrian Series 2Stage 4), Marwar Supergroup, India. Journal of Earth System Science, 127, Issue-5, 1-31.

Sharma, M. (1996). Microbialites (stromatolites) from Mesoproterozoic Salkhan Limestone, Semri Group, Rohtas, Bihar; their systematic and significance. Memoir Geological Society of India, 36, 167-196.

Singh, A. K., Chakraborty, P. P., Sarkar,S., (2018). Redox structure of Vindhyan hydrosphere: clues from total organic carbon, transition metal (Mo, Cr) concentrations and stable isotope (delta C-13) chemistry Current Science, 115, Issue-7, 1334-1341.

Sur, S., Schieber, S. and Banerjee, S., (2006). Petrographic observations suggestive of microbial mats from Rampur Shale and Bijaigarh Shale, Vindhyan basin, India. Journal of Earth Systems Science, 115, 61-66.

Vail, P.R., Mitchum, R.M. Jr.,Thompson, S III., (1977). Seismic stratigraphy and global changes of sea level: Part 4. Global cycles of relative changes of sea level: Section 2. Application of seismic reflection configuration to stratigraphic interpretation. AAPG Special, 165, 83-97.

Van Loon, A.J., Mazumder, R., (2013). First find of biogenic activity in the Palaeoproterozoic of the Singhbhum craton (E India). Geologos, 19, 185-192.

Van Wagoner, J.C., Mitchum, R. M., Campion, K. M., Rahmanian, V. D., (1990). Siliciclastic Sequence Stratigraphy in Well Logs, Cores, and Outcrops: Concepts for High-Resolution Correlation of Time and Facies. AAPG Methods in Exploration Series No. 7, iii-55.

Van Wagoner, J. C., Posamentier, H. W., Mitchum, R. M., Vail, P. R., Sarg, J. F., Loutit, T. S., and Hardenbol, J., (1988). An Overview of The Fundamentals of Sequence Stratigraphy and Key Definitions. The Society of Economic Paleontologists and Mineralogists (SEPM) Special Publication No. 42, 39-45. 


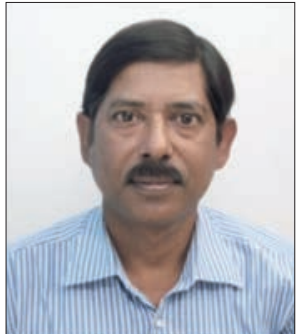

Dr. Subir Sarkar is a Professor at the Department of Geological Sciences, Jadavpur University, Kolkata, India. He has more than 25 years of experience in teaching and about 30 years in research. His research interests include Sedimentology/ Biosedimentology and basin evolution. Dr. Sarkar has published more than 100 research articles in peer-reviewed national and international journals and conference proceedings. He has also published 16 book chapters and edited four books.

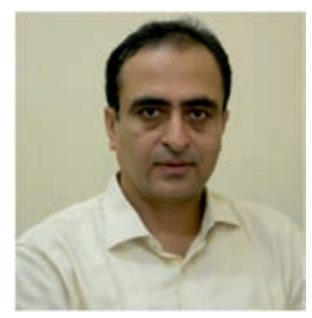

Dr. Santanu Banerjee is a Professor at the Department of Earth Sciences, Indian Institute of Technology Bombay since 1999. His research interests include microbial mat structures in Precambrian siliciclastics, origin of glauconite, sequence stratigraphy and petroleum geology. He has worked extensively on sedimentary facies and basin analysis in the Precambrian Vindhyan basin of central India and Meso-Cenozoic Kutch basin. He has published more than 115 research articles in peer-reviewed journals, contributed for 20 book chapters and edited 2 books.

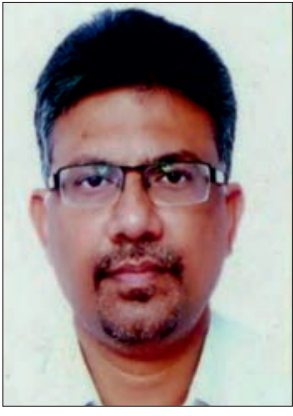

Partha Pratim Chakraborty is a Professor at University of Delhi, Delhi. He received his Masters in 1990 and Ph.D degree in 1996 from Jadavpur University, Kolkata, India. Since 2010 he has worked as a faculty at the University of Delhi. He has participated in several IGCP programs. 